\title{
Tinjauan Yuridis Mengenai Pengawasan Terhadap Pedoman Perilaku Penyiaran Platform Media Sosial Di Indonesia
}

\author{
Elwindhi Febrian \\ Fakultas Hukum Universitas Islam Indonesia Yogyakarta Indonesia \\ Jln. Cik Di Tiro No. 1 Yogyakarta Indonesia \\ elwindidifebrian@gmail.com
}

\begin{abstract}
The purpose of this study is to examine and analyze the supervision of code of conduct in broadcasting on social media platform based on the laws and regulations in Indonesia and to identify the law that regulates broadcasting on social media platforms considering both broadcasting and platform are regulated under different laws. The results of the study conclude that supervision of code of conduct in broadcasting on social media platform is carried out by the Ministry of Communication and Information with reference to the prohibitions regulated in Law No. 19 of 2016 on Amendments to Law No. 11 of 2008 on Electronic Information and Transactions (ITE Law). Broadcasting on social media platform has different characteristics from the definition of broadcasting stipulated in the Broadcasting Law. Based on the origin of lex specialis, ITE Law is more dominant in regulating broadcasting on social media platform hence the broadcasting code of conduct and the implementation of sanctions are still subject to the provisions stipulated in the ITE Law and its derivative regulations.
\end{abstract}

Key Words: Broadcasting code of conduct; social media platform; supervision

\begin{abstract}
Abstrak
Tujuan penelitian ini mengkaji dan menganalisis pengawasan terhadap pedoman perilaku penyiaran platform media sosial berdasarkan peraturan perundang-undangan di Indonesia dan untuk mengetahui hukum yang mengatur pengawasan penyiaran platform media sosial mengingat penyiaran dan platform media sosial masing-masing pengaturan diatur dalam undang-undang yang berbeda. Jenis penelitian adalah yuridis normatif dengan pendekatan perundang-undangan dan pendekatan konseptual. Hasil dari penelitian menyimpulkan pengawasan terhadap pedoman perilaku penyiaran platform media sosial dilakukan oleh Kementerian Komunikasi dan Informatika dengan merujuk larangan-larangan yang diatur dalam Undang-Undang Republik Indonesia Nomor 19 Tahun 2016 Tentang Perubahan Atas Undang-Undang Nomor 11 Tahun 2008 Tentang Informasi dan Transaksi Elektronik (UU ITE). Penyiaran melalui platform media sosial memiliki karakteristik yang berbeda dengan definisi penyiaran yang diatur dalam UU Penyiaran. Berdasarkan asal lex specialis UU ITE lebih dominan dalam mengatur penyiaran melalui platform media sosial sehingga pedoman perilaku penyiaran beserta penerapan sanksinya tetap tunduk kepada ketentuan yang diatur dalam UU ITE beserta peraturan-peraturan turunannya.
\end{abstract}

Kata-kata Kunci: Pengawasan; pedoman perilaku penyiaran; platform media sosial 


\section{Pendahuluan}

Penyiaran dalam platform media sosial merupakan penyiaran dalam bentuk audio visual over the top (OTT). OTT didefinisikan sebagai layanan yang disampaikan melalui jaringan atau infrastruktur milik operator tetapi tidak secara langsung melibatkan operator, secara sederhana adalah jasa layanan penyiaran tanpa mengikut sertakan operator jadi muatan materi konten diserahkan kepada pengguna jasa. ${ }^{1}$

Undang-Undang Republik Indonesia Nomor 32 Tahun 2002 tentang Penyiaran (UU Penyiaran) menjelaskan definisi penyiaran dalam Pasal 1 ayat (2) dengan bunyi "Penyiaran adalah kegiatan pemancarluasan siaran melalui sarana pemancaran dan/atau sarana tranmisi di darat, di laut atau di antariksa dengan menggunakan spektrum frekuensi radio melalui udara, kabel, dan/atau media lainnya untuk dapat diterima secara bersamaan oleh masyarakat dengan perangkat penerima. $^{2}$

Pengaturan definisi penyiaran dalam UU Penyiaran tidak menyebutkan penyiaran melalui jaringan / infratruktur internet atau over the top, dengan demikian penyiaran melalui platform media sosial masih menjadi pertanyaan apakah tunduk kepada UU Penyiaran atau undang-undang lain. Mengenai hal tersebut pihak RCTI dan iNews TV (MNC Group) mengajukan uji materiil kepada Mahkamah Konstitusi yang pada intinya meminta agar definisi penyiaran yang disebut dalam Pasal 1 ayat (2) UU Penyiaran agar mencakup penyelenggara jasa layanan audio visual over-the-top (OTT), atau platform digital berbasis internet seperti Youtube, Instagram, atau Facebook. ${ }^{3}$ RCTI dan iNews berdalih permohonan uji materi UU Penyiaran tersebut untuk kesetaraan dan tanggungjawab moral bangsa dilatarbelakangi keinginan untuk melahirkan perlakuan dan perlindungan yang setara seluruh masyarakat Indonesia. ${ }^{4}$

Apabila uji materiil dalam paragraf diatas dikabulkan oleh Mahkamah Konstitusi secara sendirinya pengawasan pedoman perilaku penyiaran platform media sosial menjadi kewenangan Komisi Penyiaran Indonesia. Komisi Penyiaran Indonesia yang disingkat KPI diatur dalam Bagian Kedua Komisis Penyiaran UU Penyiaran. Salah satu tugas dan kewajiban KPI menjamin masyarakat untuk

\footnotetext{
${ }^{1}$ Fauzi Cahyo Pratomo, Mengenal Over The Top (OT'T) Comunication Service dan Pengaturannya di Indonesia, https://bahasan.id/mengenal-over-the-top-ott-communication-services-dan-pengaturannya-diindonesia/, Akses 14 Oktober 2020 pukul 14.29 WIB

2 Pasal 1 ayat (2) UU No. 32 Tahun 2002 tentang Penyiaran

3 Resty Woro Yuniar, RCTI dan iNews TV gugat definisi 'penyiaran' ke MK : Demi Melindungi Kreativitas atau Tidak Mau Beradaptasi pada Perubahan, https://www.bbc.com/indonesia/majalah-54015668, Akses 14 Oktober 2020 pukul 16.08 WIB.

${ }^{4}$ https://news.detik.com/berita/d-5151302/moral-jadi-alasan-rcti-gugat-uu-penyiaran, Moral Jadi Alasan RCTI Gugat UU Penyiaran, Akses 14 Oktober 2020 pukul 16.25 WIB
} 
memperoleh informasi yang layak dan benar dengan hak asasi manusia. ${ }^{5}$ Menurut Ahmad M Ramli Dirjen Penyelenggara Pos dan Informatika (PPI) Kemenkominfo "apabila kegiatan-kegiatan tersebut dikategorikan sebagai penyiaran, maka lembaga negara, lembaga pendidikan, konten kreator baik badan usaha ataupun badan hukum yang menggunakan platform OTT harus memiliki izin sebagai lembaga penyiaran. ${ }^{6}$

Ketua KPI Agung Suprio menyatakan, KPI perlu mengawasi Netflix dan Youtube karena generasi digital sudah lebih banyak mengkonsumsi media baru dari pada media konvensional. Konten-konten media diyakini bisa mengubah karakter bangsa sehingga pengawasan perlu dilakukan, konten itu harus sesuai dengan falsafah atau kepribadian bangsa, tayangan kekerasan tidak boleh tayang pada jam anak dalam penyiaran konvensional sedangkan di media baru tidak berlaku. ${ }^{7}$ Yang disampaikan oleh Ketua KPI terkait tayangan kekerasan pada jam anak adalah bagian dari pedoman perilaku penyiaran. Pedoman perilaku penyiaran adalah ketentuan-ketentuan bagi lembaga penyiaran yang ditetapkan oleh Komisi Penyiaran Indonesia sebagai panduan tentang batasan perilaku penyelenggaraan penyiaran dan pengawasan nasional. ${ }^{8}$

KPI diberikan kewenangan untuk melakukan pengawasan sekaligus memberikan sanksi adminstratif terhadap program siaran yang bertentangan dengan pedoman perilaku penyiaran, sanksi yang dapat diberikan kepada pelanggar pedoman perilaku penyiaran adalah sanksi administrasi, jika penyiaran melalui platform sosial media tunduk kepada UU Penyiaran maka KPI juga dapat memberikan sanksi administratif kepada konten kreator di platform sosial media.

\section{Rumusan Masalah}

Tulisan ini memliki rumusan masalah yaitu bagaimana pengawasan terhadap pedoman perilaku penyiaran platform media sosial di Indonesia?

${ }^{5}$ Pasal 8 ayat (3) huruf a UU No. 32 / 2003 tentang Penyiaran

${ }^{6}$ Sania Mashabi, KPI : Putusan MK atas Uji Materil UU Penyiaran Jangan Sampai Memasung Kebebasan Berekspresi, https://nasional.kompas.com/read/2020/08/28/18235281/kpi-putusan-mk-atas-uji-materil-uupenyiaran-jangan-sampai-memasung?page=all, Akses 14 Oktober 2020 pukul 16.35 WIB.

7 KPI ingin Awasi Konten Netflix \& Youtube, Anda Setuju?, https://www.cnbcindonesia.com/ tech/20190809192202-37-91065/kpi-ingin-awasi-konten-netflix-youtube-anda-setuju, Akses 16 Oktober 2020 pukul 15.30 WIB.

${ }^{8}$ Pasal 1 ayat (1) Peraturan Komisi Penyiaran Indonesia Nomor 01/P/KPI/03/ 2012 tentang Pedoman Prilaku Penyiaran 


\section{Tujuan Penelitian}

Mengkaji dan menganalisis pengawasan terhadap pedoman perilaku penyiaran platform media sosial berdasarkan peraturan perundang-undangan di Indonesia untuk mengetahui hukum yang mengatur pengawasan penyiaran platform media sosial mengingat penyiaran dan platform media sosial masingmasing pengaturan diatur dalam undang-undang yang berbeda.

\section{Metode Penelitian}

Jenis penelitian yuridis normatif, penelitian hukum normatif adalah penelitian hukum yang meletakkan hukum sebagai sebuah bangunan sistem norma. Sistem norma yang dimaksud adalah mengenai asas-asas, norma, kaidah dari peraturan perundang-undangan, putusan pengadilan, perjanjian serta doktrin (ajaran). ${ }^{9}$

Pendekatan penelitian yang digunakan adalah metode pendekatan perundang-undangan (statute Approach) dengan tujuan menemukan asas atau doktrin hukum positif yang berlaku atau disebut sebagai studi dogmatik atau yang dikenal dengan doctrinal research. ${ }^{10}$ Selain itu menggunakan pendekatan Konseptual (conceptual approach), pendekatan ini dilakukan manakala peneliti tidak beranjak dari aturan hukum yang ada karena belum adanya aturan hukum untuk masalah yang dihadapi. ${ }^{11}$

Data penelitian dan bahan hukum terdiri dari bahan hukum primer, sekunder, dan tersier. Bahan hukum primer adalah semua aturan hukum yang dibentuk dan/atau dibuat secara resmi oleh suatu lembaga negara dan/atau badan-badan pemerintahan. ${ }^{12}$ Bahan hukum sekunder adalah seluruh informasi tentang hukum yang berlaku atau yang pernah berlaku di suatu negara secara forrmal. ${ }^{13}$ Bahan hukum tersier merupakan bahan-bahan yang termuat dalam kamus-kamus hukum, berbagai terbitan yang memuat indeks hukum dan semacamnya seperti kamus-kamus hukum, ensiklopedia, bibligrafi atau daftar pustaka, katalog-katalog terbitan, buku-buku sitasi, atau buku-buku yang memuat indeks dan sebangsanya. ${ }^{14}$ Teknik pengumpulan data menggunakan studi kepustakaan dan pengamatan konten penyiaran melalui platform media

\footnotetext{
9 Mukti Fajar \& Yulianto Achmad, Dualisme Penelitian Hukum Normatif \& Empiris, Pustaka Pelajar, Yogyakarta, 2013, hlm. 34. 86.

${ }^{10}$ Bambang Sunggono, Metode Penelitian Hukum, Cetakan ke 14, PT Grafindo Persada, Jakarta, 2013, hlm.

11 Peter Mahmud Marzuki, Penelitian Hukum, Edisi Revisi, Kencana, Jakarta, 2011, hlm.177. hlm. 81 .

12 Soetandyo Wignjosoebroto, Hukum Konsep dan Metode, Cetakan pertama, Setara Press, Malang, 2013,

${ }^{13}$ Ibid., hlm. 82.

${ }^{14}$ Ibid., hlm. 84.
} 
sosial kemudian Setelah data primer dan sekunder dikumpulkan, selanjutnya kategorisasikan, diklarifikasikan, ditabulasikan dan diinterpretasikan, kemudian melakukan analisis bahan hukum. Analisis akan sangat tergantung dari bentuk data yang terkumpul serta jenis penelitian yang dilakukan dan pendekatan yang digunakan. ${ }^{15}$

\section{Hasil Penelitian dan Pembahasan}

Penyiaran merupakan kegiatan pemancarluasan siaran melalui sarana pemancaran dan/atau sarana tansmisi di udara, di laut atau di antariksa dengan menggunakan spektrum frekuensi radio melalui udara, kabel, dan/atau media lainnya untuk dapat diterima secara serentak dan bersamaan oleh masyarakat dengan perangkat penerima siaran. ${ }^{16}$ Siaran itu sendiri menurut Pasal 1 ayat (1) UU Penyiaran adalah pesan atau rangkaian pesan dalam bentuk suara, gambar, atau suara dan gambar atau yang berbentuk grafis, karakter, baik yang bersifat interaktif maupun tidak, yang dapat diterima melalui perangkat penerima siaran.

Siaran yang diatur dalam UU Penyiaran merupakan siaran yang penyiarannya menggunakan spektrum frekuensi radio, yang merupakan sumber daya alam terbatas dan merupakan kekayaan nasional. Penggunaan spektrum frekuensi radio selayaknya dipergunakan untuk sebesar-besarnya kemakmuran rakyat sesuai dengan semangat cita-cita Proklamasi 17 Agustus 1945.17

Penyiaran dan siaran merupakan satu kesatuan yang tidak dapat dipisahkan, inti dari penyiaran merupakan penyampaian pesan atau rangkaian pesan kepada penerima siaran yaitu masyarakat Indonesia. Penyiaran tersebut dapat diterima secara serentak, jadi setiap orang dimungkinkan dapat melihat siaran tersebut tanpa pengecualian baik anak-anak, lansia, usia produktif, lakilaki, perempuan, pemeluk agama Islam, pemeluk agama Hindu, dan golongan masyarakat lainnya. Tidak adanya pembatasan penerima siaran maka negara perlu mengatur mengenai penyiaran sedemikian rupa sehingga masyarakat Indonesia sebagai penerima siaran terlindungi dari konten-konten yang negatif dan bersifat distruktif. UU No. 32 Tahun 2002 tentang Penyiaran dalam Konsideran Menimbang huruf e berbunyi "bahwa siaran yang dipancarkan dan diterima secara bersamaan. Serentak dan bebas, memiliki pengaruh yang besar dalam pembentukan pendapat, sikap, dan perilaku khalayak, maka

\footnotetext{
hlm. 107

16 Pasal 1 ayat (2) UU No. 32 Tahun 2002 tentang Penyiaran

${ }_{17}$ Menimbang huruf b UU No. 32 Tahun 2002 tentang Penyiaran
}

${ }^{15}$ Suratman dan Philips Dillah, Metode Penelitian Hukum, Cetakan ketiga, ALFABETA, Bandung, 2015, 
penyelenggara penyiaran wajib bertanggungjawab dalam menjaga nilai moral, tata susila, budaya, kepribadian dan kesatuan bangsa yang berlandaskan kepada Ketuhanan Yang Maha Esa dan kemanusian yang adil dan beradab. ${ }^{18}$

Lembaga penyiaran mempunyai peran penting dalam kehidupan sosial, budaya, politik, dan ekonomi, dan diberikan kebebasan. Sebagai media komunikasi massa yang hadir di tengah-tengah kehidupan masyarakat dalam melakukan penyiaran harus tetap bertanggungjawab dalam menjalankan fungsinya baik sebagai media informasi, pendidikan, hiburan, serta kontrol dan perekat sosial. ${ }^{19}$ Melihat peran lembaga penyiaran yang memiliki posisi strategis dalam membangun kehidupan sosial, budaya, politik dan ekonomi maka memang sangat diperlukan adanya pengawasan kepada lembaga penyiaran.

Di Indonesia terdapat Komisi Penyiaran Indonesia (KPI) yang diberikan kewenangan mengawasi lembaga penyiaran. Bagian kedua Komisi Penyiaran Indonesia Pasal 7 sampai dengan Pasal 12 UU tentang Penyiaran mengatur tugas dan fungsi KPI. KPI merupakan lembaga negara yang bersifat independent mengatur mengenai penyiaran dengan KPI pusat berkedudukan di tingkat pusat dan KPI daerah di tingkat Provinsi. Dalam menjalankan tugasnya KPI diawasi oleh DPR RI di tingkat pusat dan DPRD Provinsi di tingkat daerah. KPI merupakan wujud peran serta masyarakat berfungsi mewadahi aspirasi serta mewakili kepentingan masyarakat. ${ }^{20}$

Pasal 8 ayat (2) UU Penyiaran menjelaskan KPI mempunyai wewenang : a. Menetapkan standar program siaran, b. Menyusun peraturan dan menetapkan pedoman perilaku penyiaran, c. Mengawasi pelaksanaan peraturan dan pedoman perilaku penyiaran serta standar program siaran, d. Memberikan sanksi terhadap pelanggaran peraturan dan pedoman perilaku penyiaran serta standar program siaran, e. Melakukan koordinasi dan/atau Kerjasama dengan Pemerintah, lembaga penyiaran, dan masyarakat. ${ }^{21}$ Kemudian Pasal 8 ayat (3) menjelaskan KPI mempunyai tugas dan kewajiban : a. Menjamin masyarakat untuk memperoleh informasi yang layak dan benar sesuai dengan hak asasi manusia, $b$. Ikut membantu pengaturan infrastruktur bidang penyiaran, c. Ikut membangun iklim persaingan yang sehat antar lembaga penyiaran dan industri terkait, $\mathrm{d}$. Memelihara tatanan informasi nasional yang adil, merata, dan seimbang, e. Menampung, meneliti, dan menindaklanjuti aduan, sanggahan, serta kritik dan apresiasi masyarakat terhadap penyelenggaraan penyiaran, dan, f. Menyusun

\footnotetext{
18 Menimbang huruf e UU No. 32 Tahun 2002 tentang Penyiaran

${ }^{19}$ Menimbang huruf d UU No. 32 Tahun 2002 tentang Penyiaran

20 Pasal 7 dan 8 ayat (1) UU No. 32 Tahun 2002 tentang Penyiaran

${ }^{21}$ Pasal 8 ayat (2) UU No. 32 Tahun 2002 tentang Penyiaran
} 
perencanaan pengembangan sumber daya manusia yang menjamin profesionalitas di bidang penyiaran. ${ }^{22}$

Melihat kewenangan, fungsi, dan tugas KPI pada paragraf sebelumnya memperlihatkan bahwa komisisi tersebut memiliki cakupan yang cukup luas dalam menjalankan kewenangan, fungsi dan tugasnya bahkan memiliki kewenangan untuk memberikan sanksi kepada pelanggar pedoman perilaku penyiaran. Pedoman perilaku penyiaran diatur dalam Pasal 48 UU Penyiaran dengan ketentuan sebagai berikut :

Tabel 1.

Ketentuan Pedoman perilaku Penyiaran UU No. 32 / 2002 tentang Penyiaran

\begin{tabular}{|c|c|}
\hline Pasal & Bunyi Pasal \\
\hline Pasal 48 ayat (1) & $\begin{array}{l}\text { Pedoman perilaku penyiaran bagi penyelenggaraan siaran } \\
\text { ditetapkan oleh KPI }\end{array}$ \\
\hline Pasal 48 ayat (2) & $\begin{array}{l}\text { Pedoman perilaku penyiaran sebagaimana dimaksud dalam ayat } \\
\text { (1) disusun dan bersumber pada : a. Nilai-nilai agama, moral dan } \\
\text { peraturan perundang-undangan yang berlaku, b. Norma-norma } \\
\text { lain yang berlaku dan diterima oleh masyarakat umum dan } \\
\text { lembaga penyiaran }\end{array}$ \\
\hline Pasal 48 ayat (3) & $\begin{array}{l}\text { KPI wajib menerbitkan dan mensosialisasikan pedoman perilaku } \\
\text { penyiaran kepada Lembaga Penyiaran dan Masyarakat umum }\end{array}$ \\
\hline Pasal 48 ayat (4) & $\begin{array}{l}\text { Pedoman perilaku penyiaran menentukan standar isi siaran yang } \\
\text { sekurang-kurangnya berkaitan dengan: a. rasa hormat terhadap } \\
\text { pandangan keagamaan, b. rasa hormat terhadap hal pribadi, c. } \\
\text { kesopanan dan kesusilaan d. pembatasan adegan seks, } \\
\text { kekerasan, dan sadisme, d. perlindungan terhadap anak-anak, } \\
\text { remaja, dan perempuan, f. penggolongan program dilakukan } \\
\text { menurut usia khalayak, g. penyiaran program dalam bahasa } \\
\text { asing, h. ketepatan dan kenetralan program berita, i. siaran } \\
\text { langsung, j. siaran ulang }\end{array}$ \\
\hline Pasal 48 ayat (5) & KPI memfasilitasi pembentukan kode etik penyiaran \\
\hline
\end{tabular}

Melalui Peraturan Komisi Penyiaran Indonesia Nomor 01/P/KPI/03/2012 tentang Pedoman Perilaku Penyiaran, pedoman perilaku penyiaran mengatur lebih rinci terkait pedoman perilaku penyiaran yang pada intinya standar program siaran harus memenuhi pedoman perilaku sebagai berikut : 1) Penghormatan terhadap nilai-nilai kesukuan, agama, ras, dan antargolongan, 2) Penghormatan terhadap nilai dan norma kesopanan dan kesusilaan, 3) Penghormatan terghadap etika profesi, 4) Perlindungan kepentingan publik, 4) Menyiarkan program siaran layanan publik, 5)

22 Pasal 8 ayat (3) UU No. 32 Tahun 2002 tentang Penyiaran 
Penghormatan terhadap hak privasi, 6) Perlindungan kepada anak, 7) Perlindungan kepada orang dan kelompok masyarakat tertentu, 8) Pembatasan siaran bermuatan kekerasan, 9) Pelarangan dan/atau pembatasan siaran terkait rokok, napza, dan minuman berakohol, 10) Pelarangan siaran terkait perjudian, Pelarangan dan/atau pembatasan program siaran bermuatan mistik, horror, dan supranatural. 11) Penggolongan program siaran, 12) Prinsip-prinsip jurnalistik, 13) Batas-batas peliputan terorisme, 14) Batas-batas peliputan bencana, 15) Persyaratan perekaman tersembunyi program jurnalistik dan non jurnalistik, 15) Etika pencegatan narasumber, 16) Etika kepada narasumber baik anak-anak maupun dewasa dan sumber informasi, 17) Etika pewancara, 18) Ketentuan penggunaan bahasa, bendera, lambang negara, dan lagu kebangsaan, 19) Penggunaan sensor. ${ }^{23}$

Terkait pemberian sanksi dari KPI kepada lembaga penyiaran yang melanggar pedoman perilaku penyiaran diatur dalam Peraturan Komisi Penyiaran Nomor 02/P/KPI/03/2012 Tentang Standar Program Siaran. Peraturan ini lebih mengerucutkan definisi-definisi pedoman perilaku penyiran yang dirumuskan dalam Peraturan Komisi Penyiaran Indonesia Nomor 01/P/KPI/03/2012 tentang Pedoman perilaku Penyiaran, serta mengatur mengenai penerapan sanksi oleh KPI yang diatur dalam BAB XXX Sanksi dan Penanggungjawab sebagai berikut:

Tabel 2.

BAB XXX Sanksi dan Penanggungjawaban dalam Peraturan Komisi Penyiaran Nomor 02/P/KPI/03/2012 tentang Standar Program Siaran

\begin{tabular}{cl}
\hline \multicolumn{1}{c}{ Pasal } & \multicolumn{1}{c}{ Bunyi Pasal } \\
\hline Pasal 75 ayat (1) & $\begin{array}{l}\text { Program siaran yang terbukti secara sah dan meyakinkan } \\
\text { melanggar standar program siaran dijatuhkan sanksi administrasi }\end{array}$ \\
& oleh KPI. \\
Pasal 75 ayat (2) & Sanksi administrasi sebagaimana pada ayat (1) di atas dapat berupa: \\
& a. teguran tertulis, b. penghentian sementara mata acara yang \\
& bermasalah setelah melalui tahap tertentu, c. pembatasan durasi dan \\
& waktu siaran, d. denda administrasi, e.pembekuan kegiatan siaran \\
& untuk waktu tertentu, f. tudak diberi perpanjangan izin \\
& penyelenggara penyiaran, g. pencabutan izin penyelenggara \\
& penyiaran. \\
Pasal 76 ayat (1) & Bila terjadi pelanggaran atas standar program siaran maka yang \\
& bertanggungjawab adalah lembaga penyiaran yang menyiarkan \\
& program. \\
Pasal 76 ayat (2) & Ketentuan pada ayat (1) berlaku untuk seluruh jenis program \\
& yang diproduksi sendiri yang dibeli dari pihak lain, yang \\
& merupakan Kerjasama produksi, maupun yang disponsori. \\
\hline
\end{tabular}

${ }^{23}$ Peraturan Komisi Penyiaran Indonesia Nomor 01/P/KPI/03/2012 tentang Pedoman Prilaku Penyiaran 
Pemberian sanksi diawali dengan teguran tertulis oleh KPI kepada lembaga penyiaran sebanyak 2 kali yang masing-masing teguran selama 7 hari kalender tertulis. Apabila teguran tidak diperhatikan oleh lembaga penyiaran maka KPI akan menjatuhkan sanksi administrasi yang diatur dalam Pasal 75 ayat (2) Peraturan Komisi Penyiaran Nomor 02/P/KPI/03/2012 Tentang Standar Program Siaran. ${ }^{24}$

Penyiaran melalui platform sosial media merupakan penyampaian siaran atau konten berbasis internet, berbeda dengan penyiaran konvensional yang diatur dalam UU Penyiaran yang penyiarannya menggunakan spektrum frekuensi radio yang dapat diterima secara serentak. Internet merupakan jaringan terluas dalam sistem teknologi informasi yang dapat menghubungkan perangkat di seluruh dunia. Jaringan internet dapat diakses publik melalui jaringan world wide web (www) baik dalam bentuk teks, musik, foto, video, dan data / informasi lainnya. ${ }^{25}$ Internet adalah sistem jaringan komputer global yang saling terhubung menggunakan protocol internet (TCP/IP) untuk menghubungkan perangkat komputer di seluruh dunia. Internet adalah jaringan dari banyak jaringan yang terdiri dari jaringan pribadi, umum, akademik, bisnis, dan pemerintah lokal. Dihubungkan oleh barisan bahasa pemrograman yang luas mencakup peralatan elektronik, nirkabel, dan teknologi jaringan optik. ${ }^{26}$

Sosial media merupakan sarana untuk berinteraksi, berkomunikasi, dan membangun jaringan melalui media komunikasi online. Media sosial merupakan perkembangan mutakhir dari teknologi-teknologi web baru berbasis internet, yang memudahkan semua orang untuk berkomunikasi, berpartisipasi, saling berbagi dan membentuk sebuah jaringan online, sehingga dapat menyebarluaskan konten mereka sendiri. Post di blog, tweet, atau video Youtube dapat diproduksi dan dapat dilihat secara langsung oleh jutaan orang secara gratis. ${ }^{27}$

Penyiaran dalam platform media sosial merupakan penyiaran dalam bentuk audio visual over the top (OTT). OTT didefinisikan sebagai layanan yang disampaikan melalui jaringan atau infrastruktur milik operator tetapi tidak secara langsung melibatkan operator, secara sederhana adalah jasa layanan penyiaran

24 Pasal 78 dan Pasal 79 Peraturan Komisi Penyiaran Indonesia Nomor 02/P/KPI/03/2012 tentang Standar Program Siaran

25 Yonada Nancy, Pengertian, Fungsi, \& Perbedaan Internet, Intranet, dan Ekstranet,https://tirto.id/pengertian-fungsi-perbedaan-internet-intranet-dan-ekstranet-ely8, Akses 15 Oktober 2020 pukul 16.01 WIB.

26 Fajar Hidayanto dan Mohammad Zidni Ilmi, "Pentingnya Internet Sehat", Jurnal Inovasi dan Kewirausabaan, Vol. 4, No. 1, Januari 2015, hlm. 21.

${ }^{27}$ Yuni Fitriani, “Analisis Pemanfaatan Berbagai Media Sosial Sebagai Sarana Penyebaran Informasi bagi Masyarakat”, Jurnal Paradigma, Vol. 19, No. 2, September 2017, hlm. 149. 
tanpa mengikutsertakan operator jadi muatan materi konten diserahkan kepada pengguna jasa. ${ }^{28}$ Penyedia media sosial tidak bertanggungjawab atas konten penyiaran yang bertentangan dengan peraturan perundang-undangan di masingmasing negara atau dikenal dengan safe Harbour yaitu memisahkan tanggungjawab penyedia layanan berbasis user generated content (USG) dengan pengguna layanan. Surat Edaran Menteri Komunikasi dan Informatika Nomor 5 Tahun 2016 tentang Batasan Tanggung Jawab Penyedia Platform dan Pedagang (Merchat) perdagangan melalui sistem elektronik (Elektronik Commerce) yang Berbentuk User Generated Content. Meskipun surat edaran tersebut mengatur mengenai bidang perdagangan elektronik tetapi didalamnya mengatur larangan konten yang akan diunggah kepada platform sosial media, missal larangan konten pornografi, kekerasan, perjudian, dan laragan lainnya. Seluruh konten menjadi tanggungjawab pengguna platform dan penyedia platform wajib melakukan sarana pengamanan dan pengaduan konten dari pengguna platform. ${ }^{29}$

Sosial media adalah bagian dari perkembangan teknologi informasi yang penggunaannya berbasis internet dengan perangkat elektronik, sehingga siaran dan/atau konten dalam sosial media merupakan bagian dari informasi dan transaksi elektronik. Di Indonesia informasi dan transaksi elektronik diatur dalam Undang-Undang Republik Indonesia Nomor 19 Tahun 2016 tentang Perubahan Atas Undang-Undang Nomor 11 Tahun 2008 tentang Informasi dan Transaksi Elektronik (UUITE). Pasal 27 dan 28 UUITE mengatur larangan konten / pesan dalam bentuk informasi dan transaksi elektronik, sebagai berikut :

Tabel. 3

Larangan informasi dan transaksi elektronik dalam UUITE

\begin{tabular}{cl}
\hline Pasal & \multicolumn{2}{c}{ Bunyi Pasal } \\
\hline Pasal 27 ayat (1) & $\begin{array}{l}\text { Setiap orang dengan sengaja dan tanpa hak mendistribusikan } \\
\text { dan/atau mentransmisikan dan/atau membuat dapat }\end{array}$ \\
& diaksesnya informasi elektronik dan/atau dokumen elektronik \\
& yang memiliki muatan melanggar kesusilaan. \\
Pasal 27 ayat (2) & $\begin{array}{l}\text { Setiap orang dengan sengaja dan tanpa hak mendistribusikan } \\
\text { dan/atau mentransmisikan dan/atau membuat dapat } \\
\text { diaksesnya informasi elektronik dan/atau dokumen elektronik } \\
\text { yang memiliki muatan perjudian. }\end{array}$ \\
\hline
\end{tabular}

${ }^{28}$ Fauzi Cahyo Pratomo, Mengenal Over The Top (OTT) Comunication Service dan Pengaturannya di Indonesia, https://bahasan.id/mengenal-over-the-top-ott-communication-services-dan-pengaturannya-diindonesia/, Akses 14 Oktober 2020 pukul 14.29 WIB

${ }^{29}$ Surat Edaran Menteri Komunikasi dan Informatika Nomor 5 Tahun 2016 Tentang Batasan Tanggung Jawab Penyedia Platform dan Pedagang (Merchat) perdagangan melalui sistem elektronik (Elektronik Commerce) yang Berbentuk User Generated Content 


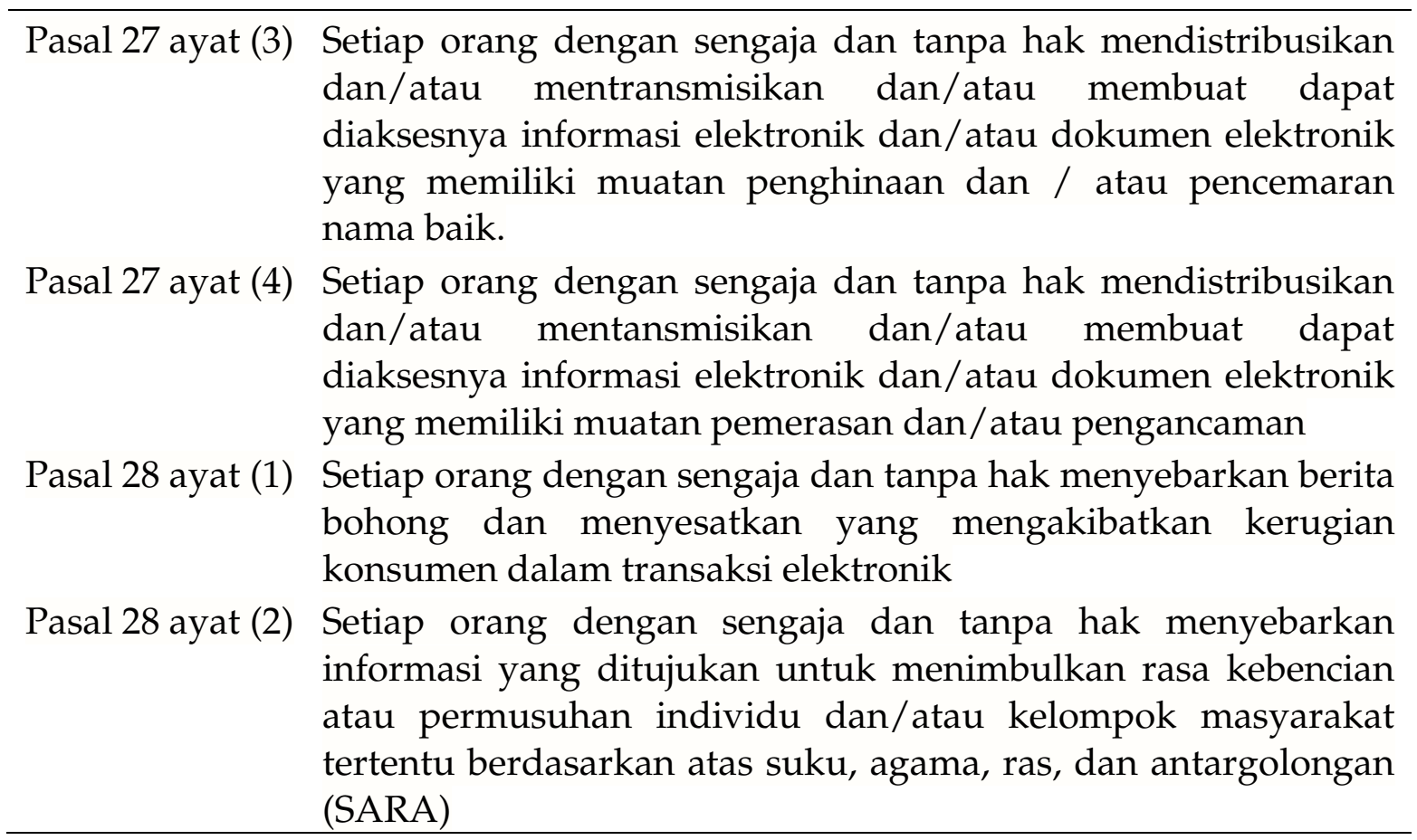

UUITE juga melindungi informasi dan dokumen elektronik yang dilindungi oleh Hak Kekayaan Intelektual serta data pribadi seseorang. ${ }^{30}$ Sehingga siaran atau konten melalui sosial media juga tidak boleh melanggar Hak Kekayaan Intelektual milik orang lain dan data pribadi milik orang lain tanpa izin setiap orang yang berhak.

Pengawasan pedoman perilaku penyiaran melalui platform media sosial memang tidak diatur dalam UUITE maupun dalam UU Penyiaran, siaran melalui platform sosial media tidak tunduk kepada UU Penyiaran sehingga pedoman perilaku penyiaran yang diatur dalam UU Penyiaran dan peraturan turunan yang dikeluarkan oleh KPI tidak dapat menjangkau siaran platform media sosial. Penyiaran melalui platform sosial media bisa saja dikategorikan memiliki kesamaan dengan definisi penyiaran dalam UU Penyiaran, kemajuan teknologi saat ini sosial media seperti Youtube, Netflix, Facebook, Instagram, Bigo Live, dan sosial media lainnya dapat melakukan siaran secara real time / live dan diterima pengguna sosial media secara serentak kecuali akun media sosial yang dapat diatur pribadi lingkup penerimanya semaki kecil yaitu pengikutnya saja yang dapat melihat. Kelebihan real time / live dalam sosial media dapat diulang dan ditonton Kembali tidak seperti penyiaran dalam spektrum frekuensi radio kecuali pihak lembaga penyiaran melakukan siaran ulang.

30 Pasal 25 dan 26 UUITE 
Meskipun tidak diatur mengenai pengawasan penyiaran melalui platform media bukan berarti para pengguna sosial media dapat seenaknya melakukan siaran tanpa memperhatikan kaidah-kaidah atau norma-norma yang ada, dengan adanya ketentuan larangan dalam UUITE Pemerintah dapat melakukan tindakan terhadap penyiaran melalui sosial media yang melanggar peraturan perundangundangan. Pasal 40 UUITE memberikan kewenangan kepada Pemerintah terkait melakukan pemanfaatan dan melakukan tindakan terhadap teknologi informasi dan transaksi elektronik, dengan pengaturan sebagai berikut:

Tabel 4.

Peran Pemerintah dalam melakukan pemanfaatan dan melakukan tindakan terhadap teknologi informasi dan transaksi elektronik.

Pasal Bunyi Pasal

Pasal 40 ayat (1) Pemerintah memfasilitasi pemanfaatan teknologi informasi dan transaksi elektronik sesuai dengan ketentuan peraturan perundang undangan.

Pasal 40 ayat (2) Pemerintah melindungi kepentingan umum dari segala jenis gangguan sebagai akibat penyalahgunaan informasi elektronik dan transaksi elektronik yang mengganggu ketertiban umum sesuai dengan ketentuan peraturan perundang-undangan.

Pasal 40 ayat (2a) Pemerintah wajib melakukan pencegahan penyebarluasan dan penggunaan informasi elektronik dan/atau dokumen elektronik yang memiliki muatan yang dilarang sesuai dengan ketentuan peraturan perundang-undangan.

Pasal 40 ayat (2b) Dalam melakukan pencegahan sebagaimana dimaksud pada ayat 2 (a), Pemerintah berwenang melakukan pemutusan akses dan/atau memerintahkan kepada penyelenggara sistem elektronik untuk melakukan pemutusan akses terhadap informasi elektronik dan/atau dokumen elektronik yang memiliki muatan yang melanggar hukum.

Pemerintah yang memiliki kewenangan melakukan tindakan melindungi dan pencegahan terhadap informasi dan transaksi elektronik adalah Menteri atau pejabat lainnya yang ditunjuk oleh Presiden, lingkungan pemerintah yang lingkup tugas dan tanggungjawabnya di bidang teknologi informasi dan transaksi elektronik adalah Kementerian Komunikasi dan Informastika (KOMINFO). Kominfo melalui Peraturan Menteri Komunikasi dan Informatika Republik Indonesia Nomor 19 Tahun 2014 tentang Penanganan Situs Internet Bermuatan Negatif dapat melakukan pemblokiran situs internet bermuatan negatif agar situs internet bermuatan negatif tidak dapat diakses. Jenis situs internet bermuatan negatif adalah situs yang bermuatan pornografi dan kegiatan 
illegal lainnya berdasarkan ketentuan peraturan perundang-undangan. Kominfo melalui Dirjen yang membidangi aplikasi informatika memberikan peringatan kepada penyedia situs terkait adanya muatan negatif dan kemudian meminta kepada penyedia atau pemilik situs untuk melakukan pemblokiran atau penghapusan. Apabila tidak diindahkan maka meminta kepada penyelenggar jasa akses internet untuk tidak dapat mengakses situs yang terdapat dalam TRUST+Positif. 31

Pasal 26 ayat (3) UUITE memerintahkan kepada "Setiap penyelenggara sistem elektronik wajib menghapus informasi elektronik dan/atau dokumen elektronik yang sudah tidak relevan sesuai dengan ketentuan peraturan perundang-undangan. Kemudian peraturan teknisnya diatur dalam Peraturan Pemerintah Republik Indonesia Nomor 71 Tahun 2019 tentang Penyelenggara Sistem dan Transaksi Elektronik, setiap penyelenggara sistem elektronik harus menyelenggarakan sistem elektronik secara andal dan aman serta bertanggungjawab terhadap beroprasinya sistem elektronik. ${ }^{22}$ Penyelenggara sistem elektronik wajib memastikan sistem elektroniknya tidak memuat informasi elektronik dan/atau dokumen elektronik yang dilarang sesuai dengan ketentuan perundang-undangan. ${ }^{33}$ Apabila penyelenggara sistem elektronik melanggar ketentuan tersebut maka dapat dikenakan sanksi administratif berupa : a. teguran tertulis, b. denda administrasi, c. penghentian sementara, d. pemutusan akses, dan/atau e. dikeluarkan dari daftar. ${ }^{34}$ Pengenaan sanksi administratif tidak menghapuskan tanggungjawab pidana dan perdata. ${ }^{35}$

Salah satu contoh platform sosial media yang memiliki aturan larangan yang ketat terkait konten adalah Situs Web Youtube, Larangan bagi pengguna Youtube mengenai konten yang akan disiarkan melalui Youtube adalah : a. Konten seksual atau ketelanjangan, b) konten yang merugikan dan berbahaya, seperti halnya menampilkan tindakan beresiko atau berbahaya, c) Konten yang mengandung kebencian, d) Konten kekerasan atau vulgar, e) Pelecehan dan Cyberbullying, f) Spam, metadata yang menyesatkan dan scam, g) Ancaman, f) Melanggar Hak Cipta, h) Melanggar privasi, i) Peniruan identitas, j)

\footnotetext{
31 Peraturan Menteri Komunikasi dan Informatika Republik Indonesia Nomor 19 Tahun 2014 tentang Penanganan Situs Internet Bermuatan Negatif

32 Pasal 3 ayat (1) Peraturan Pemerintah Republik Indonesia Nomor 71 Tahun 2019 tentang Penyelenggara Sistem dan Transaksi Elektronik

33 Pasal 5 ayat (1) Peraturan Pemerintah Republik Indonesia Nomor 71 Tahun 2019 tentang Penyelenggara Sistem dan Transaksi Elektronik

34 Pasal 100 ayat (2) Peraturan Pemerintah Republik Indonesia Nomor 71 Tahun 2019 tentang Penyelenggara Sistem dan Transaksi Elektronik

35 Pasal 100 ayat (5) Peraturan Pemerintah Republik Indonesia Nomor 71 Tahun 2019 tentang Penyelenggara Sistem dan Transaksi Elektronik
} 
Membahayakan keselamatan anak. ${ }^{36}$ Konten yang melanggar larangan pedoman komunitas Youtube akan dihapus dari Yotube sehingga video tidak dapat ditayangkan bahkan jika dilakukan berulang pengguna youtube dimungkinkan tidak dapat menggunakan, memiliki dan membuat channel Youtube lainnya. Peringatan dan teguran dilakukan secara bertahap mulai dari peringattan, teguran pertama, teguran kedua, dan teguran ketiga. ${ }^{37}$

Penyiaran melalui platform media sosial yang melakukan larangan yang diatur dalam UUITE dapat dikenakan sanksi pidana, kejahatan menggunakan medium teknologi informatika disebut dengan kejahatan siber. Penyidik dalam kejahatan siber dilakukan oleh Penyidik Pejabat Polisi Negara Republik Indonesia dan Pejabat Pegawai Negeri Sipil di lingkungan Pemerintah yang lingkup tugas dan tanggungjawabnya di bidang Teknologi Informasi dan Transaksi Elektronik. ${ }^{38}$ Ancaman sanksi pidana berupa pidana penjara dan/atau denda.

Berdasarkan pembahasan dalam paragraf-paragraf sebelumnya, penyiaran diatur dalam UU Penyiran sedangkan platform media sosial merupakan bagian dari informasi dan transaksi elektronik diatur dalam UUITE. Terdapat 2 undangundang yang bersinggungan, fokus perlindungan masing-masing undangundang tersebut berbeda. UU Penyiaran fokus perlindungan kepada penyiaran melalui spektrum frekuensi radio sedangkan UUITE fokus perlindungan kepada informasi dan transaksi elektronik melalui sistem jaringan teknologi informatika.

Pengawasan pedoman perilaku penyiaran dalam UU Penyiaran dilakukan oleh Komisi Penyiaran Indonesia sedangkan pengawasan terkait konten dan/atau penyiaran internet bermuatan negatif dilakukan oleh Kementerian Komunikasi dan Informatika melalui Direktorat Jenderal Aplikasi Informatika. Jika dikaitkan dengan uji materi yang dilakukan oleh MNC Group kepada Mahkamah Konstitusi yang menginginkan penyiaran melalui platform media sosial termasuk dalam penyiaran yang diatur dalam UU Penyiaran, jika dikabulkan penyiaran melalui platform media sosial akan diawasi oleh KPI. Setiap pengguna platform media sosial yang melakukan penyiaran harus tunduk kepada seluruh pengaturan yang ada pada UU Penyiaran seperti izin lembaga penyiaran dan pedoman perilaku penyiaran.

Pemanfaatan media sosial terbuka untuk siapa saja, tidak seperti lembaga penyiaran konvensional yang dapat melakukan pemanfaatan hanya orang-orang tertentu dan identik dengan kelompok ekonomi kuat saja. KPI tentu saja dapat

36"Pedoman Komunitas Youtube", https://www.youtube.com/intl/id/about/policies/\#staying-safe, Akses 12 Juli 2020 Pukul 20.30 WIB.

37 Dasar-Dasar Teguran Pedoman Komunitas https://support.google.com/youtube/answer/2802032? hl=id, Akses 15 Oktober 2020 pukul 20.00 WIB.

38 Pasal 43 ayat (1) UUITE 
melakukan pengawasan kepada lembaga penyiaran karena jumlahnya yang relatif sedikit. Penyiaran melalui media sosial tidak mungkin dapat diawasi dengan cara konvensional seperti cara kerja KPI sekarang ini, dengan melihat kemudian menegur, dan memberi sanksi. Penyiaran melalui media sosial haruslah dilakukan pengawasan dengan pendekatan teknologi informatika yang dikuatkan dengan pendekatan hukum. Banyaknya pengguna media sosial dan karakteristik dari teknologi informatika haruslah menjadi pertimbangan bagi instansi yang diberikan kewenangan untuk melakukan pengawasan pedoman perilaku penyiaran melalui platform media sosial. Instansi yang memiliki kompetensi dalam hal teknologi informatika dimiliki oleh Kementerian Komunikasi dan Informatika dan Kepolisian Republik Indonesia melalui Direktorat Tindak Pidana Siber jika sudah memenuhi unsur delik pidana.

Instansi yang tepat melakukan pengawasan terhadap pedoman perilaku pengawasan melalui media sosial dapat dilihak melalui asas lex specialis sistematis. UU Penyiaran dan UUITE merupakan undang-undang khusus maka perlu dilihat menggunakan asas lex specialis sistematis. Specialis sistematis adalah objek dari definisi umum diatur lebih lengkap dalam kerangka ketentuan khusus, sebagai contoh seseorang menebang kayu secara illegal dikawasan hutan lindung. Akibat penebangan kayu secara liar adalah kerusakan lingkungan hidup. Perbuatan tersebut melanggar UU Kehutanan, di sisi lain juga melanggar UU Lingkungan Hidup. Apabila ditelaah lebih lanjut yang harus digunakan adalah UU Kehutanan karena diatur lebih lengkap dan lebih rinci dalam kerangka kehutanan. ${ }^{39}$

Menurut penulis antara UU Penyiaran dan UUITE yang lebih dominan mengatur secara umum dalam hal karakteristik kekhususan bidang penyiaran melalui platform media sosial adalah UUITE karena UUITE mengatur lebih lengkap apa itu informasi dan transaksi elektronik karena sosial media merupakan bagian dari informasi dan transaksi elektronik. Dalam UUITE memang tidak ditemukan pengaturan pedoman perilaku penyiaran, tetapi siaran atau konten dalam media sosial dalam kaca mata teknologi informatika merupakan informasi elektronik dan/atau dokumen elektronik yang disitu juga diatur mengenai larangan-larangan dalam mendistribusikan dan/atau mentransmisikan informasi elektronik dan/atau dokumen elektronik, bahkan melanggar larangan dalam UUITE diancam dengan delik pidana.

UUITE dan peraturan turunannya memang tidak secara rinci membahas mengenai pedoman perilaku penyiaran tidak selengkap pengaturan dalam UU

39 Eddy O.S Hiariej Eddy O.S Hiariej, Prinsip-Prinsip Hukum Pidana, Cahaya Atma Pustaka, Yogyakarta, 2014, hlm. 353. 
Penyiaran beserta peraturan-peraturan yang dikeluarkan oleh KPI. Penulis melihat hal ini sebagai tantangan bagi pemerintah untuk membuat suatu pembaruan hukum yang dapat mengatasi permasalahan ini, tidak dapat dipungkiri perkembang ilmu pengetahuan dan teknologi informatika memiliki sisi positif dan negatifnya. Muatan konten dalam media sosial yang negatif dapat mempengaruhi kepribadian bangsa terkhusus anak-anak dan generasi muda yang dapat terjauhkan dari nilai-nilai Pancasila sebagai falsafah kehidupan berbangsa dan bernegara.

Penyiaran atau konten melalui sosial media jika tidak dilakukan penyaringan dapat menggerus nilai-nilai yang hidup dalam masyarakat, secara kausalitas Pancasila sebelum disahkan menjadi dasar filsafat negara, nilai-nilainya sudah ada yang berasal dari bangsa Indonesia sendiri yang berupa nilai-nilai adat istiadat, kebudayaan dan nilai-nilai religious. ${ }^{40}$ Keadilan yang dicita-citakan Pancasila yang juga tercantum dalam pembukaan Undang-Undang Dasar 1945 adalah bersifat religious-sosialis, juga bersifat luhur, universal, dan jauh dari sifat sekulerindividualistis-materialistis. Hal tersebut sebagai perekat bangsa dan negara Indonesia. ${ }^{41}$

Media sosial membuka kesempatan besar bagi semua elemen masyarakat dalam meningkatkan taraf hidup mereka, semuanya memiliki kesempatan yang sama dan besar kecilnya manfaat dari pengguanaan media sosial tergantung kepada usaha dan telenta masing-masing penggunanya. Pembaruan hukum yang dilakukan tidak boleh membrangus kreativitas para konten kreator, di sisi lain pembaruaan hukum harus menguatkan perlindungan kepada masyarakat dari konten-konten negatif serta mencegah adanya konten-konten yang bertentangan dengan peraturan perundang-undangan. Satjipto Rahardjo menegaskan tidak ada pilihan lain kecuali mengembangkan secara sistematis pemikiran hukum yang berorientasi sosial, suatu pembangunan hukum, pemikiran hukum, dan ilmu hukum yang tidak menyadari kegunaannya (orientasi sosial) akan menghasilkan suatu sistem hukum yang tidak mempunyai kegunaan yang memadai bagi masyarakat. ${ }^{42}$

\section{Penutup}

Pengawasan terhadap pedoman perilaku penyiaran melalui Platform media sosial dilakukan oleh Kementerian Komunikasi dan Informatika, Kementerian

40 Maryanto, "Urgensi Pembaharuan Hukum Indonesia Berdasarkan Pancasila", Jurnal Hukum, Vol XXV, No.1, April 2011, hlm. 423.

41 Agus Budi Susilo, "Penegakan Hukum yang Berkeadilan dalam Perspekti Filasat Hermeunetika Hukum: Suatu Alternatif Solusi Terhadap Problematika Penegakan Hukum di Indonesia", Perspektif, Volume XVI No. 4, September 2011, hlm. 225.

42 Satjipto Rahardjo, Membangun dan Merombak Hukum Indonesia, Genta Publishing, Yogyakarta, 2009 , hlm. 25 . 
tersebut memiliki tugas dan tanggungjawab di bidang teknologi informatika yang memiliki kemampuan mumpuni dalam bidang teknologi informatika. Penyiaran melalui platform media sosial memiliki karakteristik yang berbeda dengan definisi penyiaran yang di atur dalam UU Penyiaran. Berdasarkan asal lex specialis sistematis UUITE lebih dominan dalam mengatur penyiaran melalui platform media sosial sehingga pedoman perilaku penyiaran beserta penerapan sanksinya tetap tunduk kepada ketentuan yang diatur dalam UUITE beserta peraturanperaturan turunannya.

Pembaruan hukum diperlukan guna mengisi kekosongan hukum yang mengatur pedoman perilaku penyiaran melalui media sosial disesuaikan dengan pedoman perilaku penyiaran yang diatur dalam UU Penyiaran beserta peraturanperaturan turunan lainnya, sehingga terwujud harmonisasi antara pengaturan pedoman perilaku penyiaran secara konvensional maupun pedoman perilaku penyiaran secara digital / melalui platform digital. Keharmonisasian hukum tersebut bertujuan untuk memberikan rasa keadilan bagi seluruh rakyat Indonesia. Pembaruan hukum diharuskan berorientasi sosial dengan mengedepankan nilai-nilai Pancasila.

\section{Daftar Pustaka}

\section{Buku}

Fajar, Mukti \& Yulianto Achmad, Dualisme Penelitian Hukum Normatif \& Empiris, Pustaka Pelajar, Yogyakarta, 2013.

Sunggono, Bambang, Metode Penelitian Hukum, Cetakan ke 14, PT Grafindo Persada, Jakarta 2013.

Suratman dan Philips Dillah, Metode Penelitian Hukum, Cetakan ketiga, ALFABETA, Bandung, 2015.

Marzuki, Peter Mahmud, Penelitian Hukum, Edisi Revisi, Kencana, Jakarta, 2011.

Wignjosoebroto, Soetandyo, Hukum Konsep dan Metode, Cetakan pertama, Setara Press, Malang, 2013.

Hiariej, Eddy O.S, Prinsip-Prinsip Hukum Pidana, Cahaya Atma Pustaka, Yogyakarta, 2014.

Rahardjo, Satjipto, Membangun dan Merombak Hukum Indonesia, Genta Publishing, Yogyakarta, 2009.

\section{Jurnal}

Maryanto, "Urgensi Pembaharuan Hukum Indonesia Berdasarkan Pancasila", Jurnal Hukum, Vol. XXV, No. 1, April 2011.

Susilo, Agus Budi, "Penegakan Hukum yang Berkeadilan dalam Perspekti Filasat Hermeunetika Hukum: Suatu Alternatif Solusi Terhadap Problematika 
Penegakan Hukum di Indonesia", Perspektif, Volume XVI No. 4, September 2011.

Fitriani, Yuni, "Analisis Pemanfaatan Berbagai Media Sosial Sebagai Sarana Penyebaran Informasi bagi Masyarakat", Jurnal Paradigma, Vol. 19, No. 2, September 2017.

Hidayanto, Fajar dan Mohammad Zidni Ilmi, "Pentingnya Internet Sehat, Jurnal Inovasi dan Kewirausahaan", Vol. 4, No. 1, Januari 2015.

\section{Internet}

Fauzi Cahyo Pratomo, Mengenal Over The Top (OTT) Comunication Service dan Pengaturannya di Indonesia, https://bahasan.id/mengenal-over-the-top-ottcommunication-services-dan-pengaturannya-di-indonesia/, Akses 14 Oktober 2020 pukul 14.29 WIB.

Resty Woro Yuniar, RCTI dan iNews TV gugat definisi 'penyiaran' ke MK : Demi Melindungi Kreativitas atau Tidak Mau Beradaptasi pada Perubahan, https://www.bbc.com/indonesia/majalah-54015668, Akses 14 Oktober 2020 pukul 16.08 WIB.

Moral Jadi Alasan RCTI Gugat UU Penyiaran https://news.detik.com/berita/d5151302/moral-jadi-alasan-rcti-gugat-uu-penyiaran, Akses 14 Oktober 2020 pukul 16.25 WIB.

Sania Mashabi, KPI : Putusan MK atas Uji Materil UU Penyiaran Jangan Sampai Memasung Kebebasan Berekspresi, https://nasional.kompas.com/read/ 2020/08/28/18235281/kpi-putusan-mk-atas-uji-materil-uu-penyiaran-jangansampai-memasung?page=all, Akses 14 Oktober 2020 pukul 16.35 WIB.

KPI ingin Awasi Konten Netflix \& Youtube, Anda Setuju?,https://www.cnbcindonesia.com/tech/20190809192202-37-91065/kpiingin-awasi-konten-netflix-youtube-anda-setuju, Akses 16 )ktober 2020 pukul 15.30 WIB.

Yonada Nancy, Pengertian, Fungsi, \& Perbedaan Internet, Intranet, dan Ekstranet, https://tirto.id/pengertian-fungsi-perbedaan-internet-intranet-dan-ekstranet-ely8, akses 15 Oktober 2020 pukul 16.01 WIB.

Fauzi Cahyo Pratomo, Mengenal Over The Top (OTT) Comunication Service dan Pengaturannya di Indonesia, https://bahasan.id/mengenal-over-the-top-ottcommunication-services-dan-pengaturannya-di-indonesia/, Akses 14 Oktober 2020 pukul 14.29 WIB.

“Pedoman Komunitas Youtube"https://www.youtube.com/intl/id/about/policies /\#staying-safe, Akses 12 Juli 2020 Pukul 20.30 WIB.

Dasar-Dasar Teguran Pedoman Komunitas, https://support.google.com/youtube/ answer/2802032?hl=id, Akses 15 Oktober 2020 pukul 20.00 WIB.

\section{Peraturan Perundang-undangan}

Undang-Undang Republik Indonesia Nomor 32 Tahun 2002 Tentang Penyiaran

Undang-Undang Republik Indonesia Nomor 19 Tahun 2016 Tentang Perubahan Atas Undang-Undang Nomor 11 Tahun 2008 Tentang Informasi dan Transaksi Elektronik 
Peraturan Pemerintah Republik Indonesia Nomor 71 Tahun 2019 Tentang Penyelenggara Sistem dan Transaksi Elektronik

Peraturan Komisi Penyiaran Indonesia Nomor 01/P/KPI/03/2012 Tentang Pedoman perilaku Penyiaran

Peraturan Komisi Penyiaran Nomor 02/P/KPI/03/2012 Tentang Standar Program Siaran

Peraturan Menteri Komunikasi' dan Informatika Republik Indonesia Nomor 19 Tahun 2014 Tentang Penanganan Situs Internet Bermuatan Negatif

Peraturan Pemerintah Republik Indonesia Nomor 71 Tahun 2019 Tentang Penyelenggara Sistem dan Transaksi Elektronik

Surat Edaran Menteri Komunikasi dan Informatika Nomor 5 Tahun 2016 Tentang Batasan Tanggung Jawab Penyedia Platform dan Pedagang (Merchat) perdagangan melalui sistem elektronik (Elektronik Commerce) yang Berbentuk User Generated Content 